\title{
Soybean meal or cotton by-products associated with urea as source of nitrogen in the diet of lactating goats
}

\section{Aldivan Rodrigues Alves ${ }^{1}$, Ariosvaldo Nunes de Medeiros ${ }^{2}$, Juliana Silva de Oliveira², Roberto Germano Costa ${ }^{3}$, Marcone Geraldo Costa ${ }^{4}$, Rita de Cássia Ramos do Egypto Queiroga ${ }^{5}$, Darklê Luiza de Souza ${ }^{6}$}

\author{
1 Programa de Pós-Graduação em Zootecnia UFPB/CCA/Areia. \\ ${ }^{2}$ Departamento de Zootecnia UFPB/CCA/Areia. \\ ${ }^{3}$ Centro de Formação de Tecnólogos UFPB/Bananeiras. \\ ${ }^{4}$ Departamento de Zootecnia UFRN/UAECA/Natal. \\ ${ }^{5}$ Departamento de Nutrição, UFPB/CCS/João Pessoa. \\ ${ }^{6}$ Programa de Doutorado Integrado em Zootecnia UFC/ UFPB/UFRPE/Areia.
}

\begin{abstract}
The objective of this study was to evaluate the influence of sources of nitrogen on the intake and digestibility of nutrients and production and chemical composition of goat milk. Soybean meal (SBM), soybean meal + urea $(\mathrm{SBM}+\mathrm{U})$, cottonseed meal + urea $(\mathrm{CM}+\mathrm{U})$, cottonseed cake + urea $(\mathrm{CC}+\mathrm{U})$ and whole cottonseed + urea $(\mathrm{WC}+\mathrm{U})$ were used, representing the different sources of nitrogen in the diet. Ten crossbred goats were used (Alpine + Saanen), weighing on average $47.90 \pm 1.94 \mathrm{~kg}$ of body weight at 30 days of lactation, distributed in a double Latin square $(5 \times 5)$ with five treatments and five periods. There was influence of the different sources of nitrogen on the intakes of dry matter (DM), organic matter (OM), crude protein (CP), ether extract (EE), neutral detergent fiber (NDF) and non-fiber carbohydrates (NFC) of animals, with the lowest values found in most of the variables studied for animals that received $\mathrm{CC}+\mathrm{U}$ and $\mathrm{WC}+\mathrm{U}$. There was an effect of diets on the $\mathrm{DM}, \mathrm{OM}, \mathrm{CP}$ and NFC digestibility coefficients. The diet with sole addition of SBM presented the best result regarding the amount of milk produced, followed by animals fed $\mathrm{SBM}+\mathrm{U}$ and $\mathrm{CM}+\mathrm{U}$ and values of $2.05 \mathrm{~kg} /$ day; $1.92 \mathrm{~kg} / \mathrm{day} ; 1.73 \mathrm{~kg} / \mathrm{day} ; 1.47 \mathrm{~kg} / \mathrm{day}$; and $1.24 \mathrm{~kg} /$ day of milk for diets with $\mathrm{SBM}, \mathrm{SBM}+\mathrm{U}, \mathrm{CM}+\mathrm{U}, \mathrm{CC}+\mathrm{U}$ and $\mathrm{WC}+\mathrm{U}$, respectively. Milk composition was also changed, and the diet with $\mathrm{WC}+\mathrm{U}$ showed higher percentages: 0.1208 and 0.0041 percent, for total solids and fat, respectively. There was no difference in nitrogen balance between treatments. The use of SBM+U and CM+U did not compromise the milk performance and characteristics, but the use of $\mathrm{CC}+\mathrm{U}$ and $\mathrm{WC}+\mathrm{U}$ is indicated in periods of low milk production.
\end{abstract}

Key Words: cottonseed cake, cottonseed meal, milk constituents, NDFi, nitrogen balance, whole cottonseed

\section{Introduction}

The quality and quantity of protein is a determinant factor in the diet of ruminants due to the high demand for this nutrient during lactation and to the response variability to different sources of nitrogen available (NRC, 2001). Soybean meal is the main source of protein for these animals for containing protein of high biological value, but according to Van Soest (1994), protein sources of high biological value may lose essential amino acids due to the high content of rumen degradable protein (RDP). Thus, alternative sources of protein with higher contents of rumen-undegradable protein (RUP) have been the focus of several studies (Pina et al., 2006).

Studies with cotton by-products such as whole cottonseed, cottonseed meal and cottonseed cake, which have considerable amounts of RUP (NRC, 2001), for lactating goats, are still scarce. The quality of these products largely depends on processing, and they have a high protein content $(32.72 \mathrm{~g} / 100 \mathrm{~g} \mathrm{DM})$ and an average fiber content (33 g/100 g DM), although they may vary depending on the amount of hulls and residual oil (Bomfim et al., 2009). An appropriate RDP:RUP ratio is also an important factor; thus, associations of these sources of urea can optimize the use of these ingredients by ruminants, since the ingested urea is hydrolyzed by the action of urease synthesized by rumen bacteria, producing ammonia and carbon dioxide, and the ammonia produced is converted into microbial protein (Harmeyer \& Martens, 1980).

The production and composition of goat milk can also be influenced by the inclusion of foods rich in protein due to the nitrogen concentration $(\mathrm{N})$ and to the profile of rumen degradation of sources of N (Wu \& Satter, 2000). However, the use of sources of protein with low rumen degradation in substitution to sources of greater degradation in many studies has led to inconclusive results, or even to negative responses in animal performance. The possible reasons for this fact are the reduction of microbial protein 
synthesis and the inclusion of sources of RUP with poor essential amino acid profile or low intestinal digestibility (Clark et al., 1992).

The objective of this study was to evaluate, in lactating goats, the effect of the use of soybean meal, cottonseed meal, cottonseed cake and whole cottonseed associated with urea on the intake and apparent digestibility of nutrients and production and chemical composition of milk.

\section{Material and Methods}

Ten Alpine $\times$ Saanen crossbred goats with average weight of $47.90 \pm 1.94 \mathrm{~kg}$ of body weight (BW) and 30 days of lactation were evaluated at the Unit for Small Ruminant Research, Universidade Federal da Paraíba, Areia, Paraíba, Brazil. The animals were treated for internal and external parasites, remaining in individual stalls with cement floors, provided with water and feeder.

Treatments consisted of diets in the form of complete mixture, composed of coast-cross hay (Cynodon dactylon) and concentrate (Table 1), with different sources of nitrogen: soybean meal (SBM; control); soybean meal + urea $(\mathrm{SBM}+\mathrm{U})$; cottonseed meal + urea $(\mathrm{CM}+\mathrm{U})$; cottonseed cake + urea $(\mathrm{CC}+\mathrm{U})$; and whole cottonseed + urea $(\mathrm{WC}+\mathrm{U})$ (Table 2), formulated according to NRC (2007) to meet the requirements of lactating goats with production of $2 \mathrm{~kg}$ / goat/day corrected for body fat percentage of 0.04 . Feed was provided immediately after milking at $07 \mathrm{~h} 30$ and $16 \mathrm{~h} 30$, allowing for a percentage of 0.2 of leftovers.

The experimental design was a Latin square $(5 \times 5)$, with five periods and five treatments represented by different sources of nitrogen in the diet, using two simultaneous squares with five animals each. The experiment lasted 100 days, divided into 5 periods of 20 days, of which the first 15 days of each period were used for adaptation of animals to the experimental diets and 5 days for data collection.
Consumption data were obtained from the records of feed supplied and leftovers during the five days of data collection of each experimental period. Leftovers were weighed individually in the morning, sampling the percentage of 0.1 , and then frozen at $-15{ }^{\circ} \mathrm{C}$. Later, ingredients and leftovers were dried in an oven with forced ventilation $\left(55-60{ }^{\circ} \mathrm{C}\right)$ for 72 hours and milled in a knife mill with sieves of $1 \mathrm{~mm}$ screen. To evaluate the DM, OM, CP, EE, NDF and NFC digestibility coefficient, feces were directly collected from the final portion of the rectum every 27 hours and each harvest period was performed on the 1st, $2 \mathrm{nd}, 3 \mathrm{rd}, 4 \mathrm{th}$ and 5 th days at $6 \mathrm{~h} 00,9 \mathrm{~h} 00,12 \mathrm{~h} 00,15 \mathrm{~h} 00$ and $18 \mathrm{~h} 00$, respectively. Samples of feces were stored at $-15^{\circ} \mathrm{C}$ and subsequently, similarly for feed and leftovers, they were processed at the end of each experimental period.

The fecal production estimation was performed using indigestible neutral detergent fiber (iNDF) as internal marker. Feces, feed and leftover samples were incubated in vitro in an artificial rumen (DAYSE II; ANKOM Technology Coorp., Fairport, NY) based on methodology described by Tilley \& Terry (1963). The amount of sample incubated was $0.8 \mathrm{~g}$ for diets (particles of $1 \mathrm{~mm}$ ), leftovers (particles of $1 \mathrm{~mm}$ ) and feces (particles of $2 \mathrm{~mm}$ ) packed in non-woven textile bags (TNT-100 $\mathrm{g} / \mathrm{m}^{2}$ ) for a period of 240 hours (Casali, 2006). The remaining material was subjected to extraction with neutral detergent and the residue was considered iNDF.

Ingredients, leftovers and feces were subjected to analyses of dry matter (DM), crude protein (CP), ether extract (EE), mineral matter (MM), neutral detergent fiber (NDF), acid detergent fiber (ADF) and lignin (Silva \& Queiroz, 2002). The determination of NDF and ADF was performed with an ANKOM device from Ankom Technology Corporation, using TNT bags $\left(100 \mathrm{~g} / \mathrm{m}^{2}\right)$. The correction of nitrogen compounds and mineral matter on the NDF and ADF were performed as recommended by

Table 1 - Nutritional composition (g/kg dry matter) of the ingredients of the experimental diets

\begin{tabular}{|c|c|c|c|c|c|c|}
\hline \multirow{2}{*}{ Item } & \multicolumn{6}{|c|}{ Ingredient } \\
\hline & Soybean meal & Cottonseed meal & Cottonseed cake & Whole cottonseed & Corn meal $^{1}$ & Coast-cross hay \\
\hline Dry matter & 876.7 & 873.7 & 876.3 & 875.7 & 887.6 & 853.6 \\
\hline Organic matter & 934.0 & 954.2 & 958.3 & 958.2 & 967.5 & 930.1 \\
\hline Protein & 473.0 & 291.4 & 310.4 & 226.2 & 105.0 & 79.8 \\
\hline Lipids & 22.4 & 33.8 & 70.8 & 195.6 & 114.9 & 21.1 \\
\hline NDFap & 92.5 & 482.1 & 437.6 & 408.1 & 245.0 & 763.5 \\
\hline ADFap & 60.2 & 364.8 & 430.3 & 377.2 & 93.8 & 509.5 \\
\hline Lignin & 15.8 & 138.6 & 122.4 & 99.8 & 23.1 & 110.8 \\
\hline Total carbohydrates & 478.3 & 608.8 & 712.0 & 512.4 & 767.3 & 836.6 \\
\hline Non-fibrous carbohydrates & 385.8 & 126.7 & 274.4 & 104.3 & 522.4 & 73.1 \\
\hline Neutral detergent insoluble protein & 57.8 & 36.2 & 30.9 & 47.3 & 21.5 & 34.5 \\
\hline Acid detergent insoluble protein & 46.2 & 14.0 & 16.7 & 25.2 & 13.3 & 24.5 \\
\hline
\end{tabular}

NDFap - neutral detergent fiber corrected for ash and protein; ADFap - acid detergent fiber corrected for ash and protein.

${ }^{1}$ Byproduct of the fabrication of cornflake. 
Table 2 - Chemical-bromatological composition of the experimental diets

\begin{tabular}{|c|c|c|c|c|c|}
\hline \multirow{2}{*}{ Item } & \multicolumn{5}{|c|}{ Treatments } \\
\hline & Soybean meal & Soybean meal + urea & Cottonseed meal + urea & Cottonseed cake + urea & Whole cottonseed + urea \\
\hline & \multicolumn{5}{|c|}{ Ingredients ( $\mathrm{g} / \mathrm{kg}$ dry matter) } \\
\hline Coast-cross hay & 469.9 & 464.5 & 443.2 & 446.2 & 455.2 \\
\hline Soybean meal & 166.8 & 110.5 & 0.0 & 0.0 & 0.0 \\
\hline Cottonseed meal & 0.0 & 0.0 & 154.7 & 0.0 & 0.0 \\
\hline Cottonseed cake & 0.0 & 0.0 & 0.0 & 145.7 & 0.0 \\
\hline Whole cottonseed & 0.0 & 0.0 & 0.0 & 0.0 & 158.5 \\
\hline Corn meal $^{1}$ & 346.6 & 399.2 & 373.9 & 374.2 & 358.3 \\
\hline Urea & 0.0 & 7.2 & 10.0 & 10.2 & 14.2 \\
\hline Mineral supplement ${ }^{2}$ & 5.2 & 7.7 & 7.4 & 16.2 & 1.0 \\
\hline \multirow[t]{2}{*}{ Calcitic limestone } & 11.6 & 10.9 & 10.7 & 7.5 & 13.0 \\
\hline & \multicolumn{5}{|c|}{ Chemical composition ( $\mathrm{g} / \mathrm{kg}$ dry matter) } \\
\hline Dry matter ${ }^{3}$ & 871.1 & 872.6 & 872.5 & 873.4 & 872.4 \\
\hline Organic matter & 928.1 & 921.5 & 921.6 & 916.7 & 921.8 \\
\hline Mineral matter & 71.9 & 78.5 & 78.4 & 83.3 & 78.2 \\
\hline Protein & 147.2 & 145.1 & 141.2 & 142.0 & 146.7 \\
\hline Lipids & 53.4 & 58.1 & 57.5 & 62.7 & 81.7 \\
\hline NDFap & 459.1 & 462.7 & 504.6 & 496.1 & 500.0 \\
\hline ADFap & 281.9 & 280.8 & 317.3 & 325.1 & 325.3 \\
\hline Lignin & 62.7 & 62.4 & 79.2 & 75.9 & 74.5 \\
\hline Total carbohydrates & 727.5 & 718.3 & 722.9 & 712.0 & 693.4 \\
\hline Non-fibrous carbohydrates & 268.3 & 268.5 & 236.4 & 234.2 & 218.9 \\
\hline Neutral detergent insoluble protein & 33.3 & 31.0 & 29.0 & 28.0 & 30.9 \\
\hline Acid detergent insoluble protein & 23.8 & 21.8 & 18.0 & 18.3 & 19.9 \\
\hline Total digestible nutrients & 637.3 & 646.6 & 589.9 & 614.0 & 642.7 \\
\hline
\end{tabular}

NDFap - neutral detergent fiber corrected for ash and protein; ADFap - acid detergent fiber corrected for ash and protein.

${ }^{1}$ Byproduct from the fabrication of cornflake.

${ }^{2}$ Mineral supplement (nutrient/kg of the supplement): vitamin A - 135,000.00 IU; vitamin D3 - 68,000.00 IU; vitamin E - 450.00 IU; calcium - 240 g; phosphorus - 71 g; potassium - 28.2 g; sulfur - 20 g; magnesium - 20 g; copper - $400 \mathrm{mg}$; cobalt - $30 \mathrm{mg}$; chromium - $10 \mathrm{mg}$; iron - 2,500 mg; iodine - $40 \mathrm{mg}$; manganese - 1,350 mg; selenium - $15 \mathrm{mg}$; zinc - 1,700 mg; maximum fluorine - $710 \mathrm{mg}$; solubility of phosphorus $(\mathrm{P})$ in citric acid - $2 \%$ (min).

${ }^{3} \mathrm{~g} / \mathrm{kg}$ of the natural matter.

Licitra et al. (1996) and Mertens (2002), respectively. For the estimation of non-fiber carbohydrates (NFC), the equation proposed by Hall et al. (2000) was used (Equation 1):

$$
N F C(\%)=100-M M-E E-N D F a p-(C P-C P u+U)
$$

The milk yield was calculated daily by individual weighing during the five days of collection, after milking the goats twice daily (07h00 and 04h00). On the 1st, 3rd and 5 th days of the collection period, milk was collected for physicochemical analyses and grouped into composite samples, proportional to the weight of each milking for each animal.

In the physicochemical analyses of milk, protein was determined using methods 991.20 and 991.23; total dry extract using method 925.23; and acidity, expressed in Dornic degrees $\left({ }^{\circ} \mathrm{D}\right)$, using method 947.05 of AOAC (1998). For the determination of fat and lactose, methods 433/IV and 432/IV of IAL (2005) were used, respectively.

The correction of milk production for fat percentage of 0.04 (FCMY) was performed according to NRC (2001) (Equation 2) and the correction of milk production for total solids (TSCMY) was performed according to Tyrrell \& Reid (1965) (Equation 3):
$\operatorname{FCMY}(0.04)(\mathrm{kg} /$ day $)=0.4 \times$ milk yeld $(\mathrm{kg} /$ day $)+15 \times$ fat $(\mathrm{kg} /$ day $)$

$$
\begin{aligned}
\operatorname{TSCMY}(\mathrm{kg} / \mathrm{day})- & (12.3 \times \mathrm{g} \text { of fat })+(6.56 \times \text { of fat solids })- \\
& (0.0752 \times \text { milk yeld in } \mathrm{kg})
\end{aligned}
$$

Feed efficiency was determined by dividing the milk production corrected for fat percentage $(0.04)$ by the dry matter intake verified over the sampling period.

At the calculation the nitrogen balance, the amounts of nitrogen ( $\mathrm{g} /$ day) consumed and excreted in milk, urine and feces were considered. The nitrogen use efficiency was obtained by dividing the nitrogen contained in the milk by the nitrogen consumed.

On the first day of the collection period, spot urine samples were collected approximately 4 hours after feeding, during spontaneous urination. Aliquots of $30 \mathrm{~mL}$ of pure urine were collected and stored at $-20{ }^{\circ} \mathrm{C}$ for nitrogen analysis using method 984.13 (AOAC, 1990) and $10 \mathrm{~mL}$ of samples were diluted into $40 \mathrm{~mL}$ of $0.036 \mathrm{~N} \mathrm{H}_{2} \mathrm{SO}_{4}$, and kept at $\mathrm{pH}$ lower than 3 , and then subjected to creatinine analysis using a commercial kit (Labtest) to estimate the urinary volume. The urine volume was obtained for each animal by multiplying body weight by the average daily 
creatinine excretion of $26.05 \mathrm{mg} / \mathrm{L}$ (Fonseca et al., 2006) and dividing this product by the creatinine concentration $(\mathrm{mg} / \mathrm{L})$ in the spot urine sample.

Data were subjected to analysis of variance using the mixed model (PROC MIXED) of the Statistical Analysis System (SAS, version 9.2), and the treatment means were compared by Tukey's test, adopting $\alpha=0.05$, using the following mathematical model:

$$
\mathrm{Y}_{\mathrm{ijkl}}=\mu+\mathrm{A}_{(\mathrm{k}) \mathrm{i}}+\mathrm{P}_{\mathrm{j}}+\mathrm{Q}_{\mathrm{k}}+\mathrm{T}_{1}+\mathrm{QT}_{\mathrm{kl}}+\xi_{\mathrm{ijkl}}
$$

where: $\mathrm{Y}_{\mathrm{i} \mathrm{j} k \mathrm{l}}=$ Observation of animal $\mathrm{i}$ (random effect), in period $\mathrm{j}$ (random effect), on square $\mathrm{k}$ (random effect), subjected to treatment 1 (fixed effect); $\mu=$ overall effect of the mean; $\mathrm{A}_{(\mathrm{k}) \mathrm{i}}=$ effect of animal $\mathrm{i}$ on square $\mathrm{k}$, with $\mathrm{i}=1$, $2,3,4,5 ; \mathrm{Pj}=$ effect of period $j ; \mathrm{Q}_{\mathrm{k}}=$ effect of the Latin square, with $\mathrm{k}=1,2 ; \mathrm{T}_{1}=$ effect of treatment 1 , with $\mathrm{l}=1,2$, $3,4,5 ; \mathrm{QT}_{\mathrm{kl}}=$ interaction of the effect with the Latin square $\times$ treatment 1 ; and $\xi_{\mathrm{ijkl}}=$ random error associated with each observation $Y_{\mathrm{ijkl}}$.

\section{Results and Discussion}

There was influence of the studied diets on the dry matter intake $\left(\mathrm{kg} /\right.$ day and $\left.\mathrm{g} / \mathrm{kg}^{0.75} \mathrm{BW}\right)$ by goats $(\mathrm{P}<0.05)$ (Table 3). Diets containing cottonseed cake with urea $(\mathrm{CC}+\mathrm{U})$ and whole cottonseed with urea $(\mathrm{WC}+\mathrm{U})$ provided animals with lower intake values $(\mathrm{P}<0.05)$ compared with control diet (SBM) when DMI was expressed in $\mathrm{kg} /$ day; however, when it was expressed in $\mathrm{g} / \mathrm{kg}^{0.75} \mathrm{BW}$, only the diet containing $\mathrm{WC}+\mathrm{U}$ showed significant difference. The dry matter intake observed for animals fed SBM, SBM+U and $\mathrm{CM}+\mathrm{U}$ was similar to the $2.02 \mathrm{~kg}$ /day recommended by the NRC (2007) for animals with an average $45 \mathrm{~kg}$ body weight and production of $2 \mathrm{~kg}$ /day of milk corrected for a fat percentage of 0.04 .

Although whole cottonseed is an oilseed rich in unsaturated fatty acids and cottonseed cake also contains a high content of this component, which may interfere with the intake of ruminants (Jenkins, 1993; Allen, 2000), the EE values in diets $\mathrm{CC}+\mathrm{U}$ and $\mathrm{WC}+\mathrm{U}$, of 62.7 and $81.7 \mathrm{~g} / \mathrm{kg}$ $\mathrm{DM}$, respectively, in this experiment, are similar to those of Brown-Crowder et al. (2001), who worked with levels up to $80.0 \mathrm{~g} / \mathrm{kg} \mathrm{EE}$ in the DM of diets for Alpine goats in early lactation and reported no reduction in DM intake. Thus, the lower DM intake by goats fed diets $\mathrm{CC}+\mathrm{U}$ and $\mathrm{WC}+\mathrm{U}$ when compared with SBM may be more associated with psychogenic factors such as the physical form of whole cottonseed and cottonseed cake than the EE content of diets, and according to Mertens (1994), psychogenic factors involving animal behavior in response to stimulatory or inhibitory factors in the diet may adversely impact feed intake.
The CP, NDF and NFC intake by animals was also influenced by diet $(\mathrm{P}>0.05)$, but no difference in the $\mathrm{EE}$ intake was found $(\mathrm{P}<0.05)$. The diet with $\mathrm{SBM}$ promoted higher $\mathrm{CP}$ intake $(\mathrm{P}<0.05)$ than diets with $\mathrm{CC}+\mathrm{U}$ and $\mathrm{WC}+\mathrm{U}$; however, for the NDF intake, only the diet with $\mathrm{WC}+\mathrm{U}$ differed from control diet. The CP intake of $0.31 \mathrm{~kg} /$ day by goats that received diet with $\mathrm{SBM} ; 0.30 \mathrm{~kg} /$ day from $\mathrm{SBM}+\mathrm{U}$; and $0.28 \mathrm{~kg} /$ day from $\mathrm{CM}+\mathrm{U}$, as well as $\mathrm{DM}$ intake, were similar to the $0.28 \mathrm{~kg} /$ day recommended by the NRC (2007), showing that these diets are able to meet the $\mathrm{CP}$ requirements for lactating goats.

The average value for NDF intake by animals of $18.4 \mathrm{~g} / \mathrm{kg}$ body weight found in this study is higher than that suggested by Mertens (1992), who proposed an average NDF intake of $12.0 \mathrm{~g} / \mathrm{kg}$ body weight, representing an intake level regulated by physical mechanisms, when stating that the filling limitation can be correlated to the level of neutral detergent fiber (NDF) of a diet. However, recommended caution when using this calculation, especially for goats raised in tropical regions, because, according to Van Soest (1994), the low energy content of forage produced in these regions, can causing the animals to consume greater amounts of feed to meet their requirements.

Diets with $\mathrm{SBM}$ and $\mathrm{SBM}+\mathrm{U}$ promoted higher NFC intake $(\mathrm{P}<0.05)$ when compared with cotton-derived diets. When using feed with a high percentage of nitrogen and rumen-degraded protein such as soybean meal and urea, it is necessary to have the contribution of carbohydrate of rapid fermentation, allowing the availability of energy and carbon skeletons for microbial protein production (Russell et al., 1992), which may explain the higher NFC intake by animals fed diets containing SBM and SBM+U.

The diet with $\mathrm{WC}+\mathrm{U}$ provided the highest $\mathrm{EE}$ percentage in the composition $(81.7 \mathrm{~g} / \mathrm{kg} \mathrm{DM})$; however, the intake of lipids by the group fed this feed, of $0.13 \mathrm{~kg}$ / day, was similar to the others ( $\mathrm{P}>0.05)$, possibly due to the selectivity and consequent rejection of whole cottonseed by animals, raising the EE content in the leftovers. According to the concept postulated by Van Soest (1994), goats are classified as intermediate selectors, being able to select the more nutritive parts of feeds.

There was an effect of diets on DM, OM, CP and NFC digestibility coefficients $(\mathrm{P}<0.05)$; however, for $\mathrm{EE}$ and NDF, treatments did not differ $(\mathrm{P}>0.05)$ (Table 3$)$. The diet with $\mathrm{CM}+\mathrm{U}$ promoted the lowest $\mathrm{DM}$ and $\mathrm{OM}$ digestibility coefficients, with 0.543 and 0.558 , respectively, when compared with diets with $\mathrm{SBM}$ and $\mathrm{SBM}+\mathrm{U}(\mathrm{P}<0.05)$. Beran et al. (2005), evaluating the ruminal degradability in situ of concentrated supplements in cattle feed, found that the heating during the oil extraction process for 
obtaining cottonseed meal can cause changes in the protein constitution, thereby decreasing its degradability, which contributes to lower digestibility and to the lower DM and $\mathrm{OM}$ digestibility coefficients of the diet with $\mathrm{CM}+\mathrm{U}$, compared with the control diet $(\mathrm{P}<0.05)$.

Also in relation to OM digestibility coefficient, the 0.576 for the diet with $\mathrm{WC}+\mathrm{C}$ was also lower than the control diet (0.635). The behavior of the low OM digestibility in diet with $\mathrm{WC}+\mathrm{U}$ when compared with the control diet can be explained by the high lipid concentration of whole cottonseed, which may have hindered the access of microorganisms to this diet and consequently affected digestibility (Palmquist, 1991). At the same time, Silva et al. (2007) suggested that the peculiar characteristics of oilseeds should be considered when provided in its whole form, since due to the presence of fiber, mostly in the hulls, they decrease the rate of passage of solids and this increase in permanence time reduces digestibility and energy value of the diet. Silva et al. (2010) studied the effect of fat supplementation in the diet of lactating goats and observed reduction in OM digestibility when the animals received $128.9 \mathrm{~g} / \mathrm{kg}$ DM from whole cottonseed in the total diet.

The CP digestibility coefficient of the diet with $\mathrm{CM}+\mathrm{U}$ was 0.662 , with no statistical difference for the coefficient 0.699 of diet with $\mathrm{CC}+\mathrm{U}$, but lower $(\mathrm{P}<0.05)$ than the digestibility coefficients of $0.738,0.729$ and 0.725 of diets with $\mathrm{SBM}, \mathrm{SBM}+\mathrm{U}$ and $\mathrm{WC}+\mathrm{U}$, respectively. Cottonseed meal showed $138.6 \mathrm{~g} / \mathrm{kg}$ DM in the lignin $\operatorname{diet}$ (Table 1), and according to Van Soest (1994), a high lignin content can also affect the digestibility of nutrients including protein.
In this study, there was no influence of different sources of protein on EE and NDF digestibility, although diets with $\mathrm{CM}+\mathrm{U}$ and $\mathrm{WC}+\mathrm{U}$ provided higher $\mathrm{EE}$ concentrations in the diet: 62.7 and $81.7 \mathrm{~g} / \mathrm{kg} \mathrm{DM}$, respectively, contrasting with results of Silva et al. (2010), who found higher EE digestibility when supplementing lactating goats with faveleira (Cnidoscolus phyllacanthus) and cottonseed cake, obtaining EE percentage in the diets of 0.066 and 0.084 , in addition to greater NDF digestibility for the animals that received whole cottonseed.

There were significant effects of diets $(\mathrm{P}<0.05)$ on production data and physicochemical composition of goat milk (Table 4), in which goats fed the diet with SBM showed higher amount of milk produced, with no statistical difference when compared with the group fed $\mathrm{SBM}+\mathrm{U}$ $(\mathrm{P}>0.05)$, but the feed efficiency (FE) of the animals was not affected by diet $(\mathrm{P}>0.05)$.

The high results for milk production by animals that received diets with $\mathrm{SBM}, \mathrm{SBM}+\mathrm{U}$ and $\mathrm{CM}+\mathrm{U}$ were due to the high DM intake ( $\mathrm{kg} / \mathrm{day})$ and $\mathrm{CP}$ values ( $\mathrm{kg} / \mathrm{day})$ by animals. Increased feed intake implies more supply of nutrients to the animal. Furthermore, Goetsch et al. (2011) reported that the effect of dietary crude protein on milk production depends on the nature of nitrogenous compounds due to their influence on the metabolizable protein intake. Milk production by animals fed diets containing $\mathrm{CM}+\mathrm{U}$ differed in relation to control only when expressed in $\mathrm{kg} /$ day $(\mathrm{P}<0.05)$.

Usually, research carried out with whole cottonseed, either to lactating cows or goats, evaluates this ingredient as source of lipid and the results of the inclusion of whole cottonseed in milk production are controversial and in some

Table 3 - Average daily intake and apparent digestibility of nutrients by lactating goats as a function of the different sources of nitrogen in the diet

\section{Treatments}

\begin{tabular}{|c|c|c|c|c|c|c|c|}
\hline \multirow[b]{2}{*}{ Item } & \\
\hline & Soybean meal & $\begin{array}{l}\text { Soybean meal } \\
+ \text { urea }\end{array}$ & $\begin{array}{l}\text { Cottonseed meal } \\
+ \text { urea }\end{array}$ & $\begin{array}{c}\text { Cottonseed cake } \\
+ \text { urea }\end{array}$ & $\begin{array}{l}\text { Whole cottonseed } \\
+\quad \text { urea }\end{array}$ & P-value & $\begin{array}{c}\text { Standard error of } \\
\text { the mean }\end{array}$ \\
\hline \multicolumn{8}{|l|}{ Intake } \\
\hline Dry matter (kg/day) & $2.05 \mathrm{a}$ & $2.02 \mathrm{ab}$ & $2.00 \mathrm{ab}$ & $1.82 \mathrm{bc}$ & $1.60 \mathrm{c}$ & 0.0001 & 0.068 \\
\hline Dry matter $\left(\mathrm{g} / \mathrm{kg}^{0.75} \mathrm{BW}\right)$ & $113.02 \mathrm{a}$ & $108.96 \mathrm{a}$ & $105.34 \mathrm{a}$ & $100.83 \mathrm{ab}$ & $87.87 \mathrm{~b}$ & 0.0001 & 3.520 \\
\hline Protein $(\mathrm{kg} /$ day $)$ & $0.31 \mathrm{a}$ & $0.30 \mathrm{a}$ & $0.28 \mathrm{ab}$ & $0.26 \mathrm{~b}$ & $0.23 \mathrm{c}$ & 0.0001 & 0.008 \\
\hline Ether extract (kg/day) & $0.12 \mathrm{a}$ & $0.13 \mathrm{a}$ & $0.12 \mathrm{a}$ & $0.12 \mathrm{a}$ & $0.13 \mathrm{a}$ & 0.3762 & 0.003 \\
\hline NDFap (kg/day) & $0.88 \mathrm{a}$ & $0.86 \mathrm{ab}$ & $0.96 \mathrm{a}$ & $0.85 \mathrm{ab}$ & $0.75 b$ & 0.0005 & 0.033 \\
\hline NDFap (g/kg $\left.{ }^{0.75} \mathrm{BW}\right)$ & $19.1 \mathrm{a}$ & $18.4 \mathrm{ab}$ & $20.3 \mathrm{a}$ & $18.6 \mathrm{a}$ & $15.7 \mathrm{~b}$ & 0.0006 & 0.070 \\
\hline Non-fibrous carbohydrates (kg/day) & $0.59 \mathrm{a}$ & $0.60 \mathrm{a}$ & $0.51 \mathrm{~b}$ & $0.47 b$ & $0.40 \mathrm{c}$ & 0.0001 & 0.013 \\
\hline \multicolumn{8}{|l|}{ Coefficients of digestibility } \\
\hline Dry matter & $0.608 \mathrm{a}$ & $0.608 \mathrm{a}$ & $0.543 b$ & $0.566 \mathrm{ab}$ & $0.562 \mathrm{ab}$ & 0.0092 & 1.592 \\
\hline Organic matter & $0.630 \mathrm{a}$ & $0.625 \mathrm{ab}$ & $0.558 \mathrm{c}$ & $0.580 \mathrm{ab}$ & $0.576 b$ & 0.0021 & 1.490 \\
\hline Protein & $0.738 \mathrm{a}$ & $0.729 \mathrm{a}$ & $0.662 b$ & $0.699 \mathrm{ab}$ & $0.725 \mathrm{a}$ & 0.0004 & 1.271 \\
\hline Ether extract & $0.724 \mathrm{a}$ & $0.709 \mathrm{a}$ & $0.689 \mathrm{a}$ & $0.715 \mathrm{a}$ & $0.743 \mathrm{a}$ & 0.5506 & 1.743 \\
\hline NDFap & $0.408 \mathrm{a}$ & $0.406 \mathrm{a}$ & $0.379 \mathrm{a}$ & $0.392 \mathrm{a}$ & $0.382 \mathrm{a}$ & 0.6183 & 2.029 \\
\hline Non-fibrous carbohydrates & $0.885 \mathrm{ab}$ & $0.892 \mathrm{a}$ & $0.850 \mathrm{a}$ & $0.875 \mathrm{a}$ & $0.863 \mathrm{a}$ & 0.0536 & 1.081 \\
\hline
\end{tabular}

Means followed by different letters in the row differ by Tukey's test $(\mathrm{P}<0.05)$.

BW - body weight; NDFap - neutral detergent fiber corrected for ash and protein. 
Table 4 - Milk yield (MY), feed efficiency and physicochemical composition of milk from goats receiving different sources of nitrogen in the diet

\begin{tabular}{|c|c|c|c|c|c|c|c|}
\hline \multirow[b]{2}{*}{ Item } & \multicolumn{7}{|c|}{ Treatments } \\
\hline & Soybean meal & $\begin{array}{l}\text { Soybean meal } \\
+ \text { urea }\end{array}$ & $\begin{array}{l}\text { Cottonseed meal } \\
+ \text { urea }\end{array}$ & $\begin{array}{l}\text { Cottonseed cake } \\
+ \text { urea }\end{array}$ & $\begin{array}{l}\text { Whole cottonseed } \\
+ \text { urea }\end{array}$ & P-value & $\begin{array}{c}\text { Standard error of } \\
\text { the mean }\end{array}$ \\
\hline \multicolumn{8}{|l|}{ Yield } \\
\hline Milk (kg/day) & $2.05 \mathrm{a}$ & $1.92 \mathrm{ab}$ & $1.73 \mathrm{bc}$ & $1.47 \mathrm{~cd}$ & $1.24 \mathrm{~d}$ & 0.0001 & 0.08 \\
\hline FCMY $0.04(\mathrm{~kg} / \text { day })^{1}$ & $1.88 \mathrm{a}$ & $1.77 \mathrm{a}$ & $1.62 \mathrm{ab}$ & $1.42 \mathrm{bc}$ & $1.25 \mathrm{c}$ & 0.0001 & 0.08 \\
\hline TSCMY (kg/day) & $1.92 \mathrm{a}$ & $1.82 \mathrm{a}$ & $1.67 \mathrm{ab}$ & $1.44 \mathrm{bc}$ & $1.27 \mathrm{c}$ & 0.0001 & 0.08 \\
\hline \multicolumn{8}{|l|}{ Efficiency } \\
\hline FE - MY/DM Intake (kg/kg) & $0.93 \mathrm{a}$ & $0.89 \mathrm{a}$ & $0.90 \mathrm{a}$ & $0.80 \mathrm{a}$ & $0.80 \mathrm{a}$ & 0.3202 & 0.06 \\
\hline \multicolumn{8}{|c|}{ Physicochemical composition of the milk (\%) } \\
\hline Total solids & $0.1132 b$ & $0.1147 b$ & $0.1156 b$ & $0.1158 b$ & $0.1208 \mathrm{a}$ & 0.0020 & 0.12 \\
\hline Non-fat solids & $0.0789 \mathrm{a}$ & $0.0794 \mathrm{a}$ & $0.0796 \mathrm{a}$ & $0.0781 \mathrm{a}$ & $0.0796 \mathrm{a}$ & 0.8832 & 0.14 \\
\hline Moisture & $0.8868 \mathrm{a}$ & $0.8853 \mathrm{a}$ & $0.8844 \mathrm{a}$ & $0.8842 \mathrm{a}$ & $0.8792 b$ & 0.0020 & 0.12 \\
\hline Mineral & $0.074 \mathrm{a}$ & $0.073 \mathrm{a}$ & $0.073 \mathrm{a}$ & $0.072 \mathrm{a}$ & $0.076 \mathrm{a}$ & 0.3014 & 0.14 \\
\hline Fat & $0.0343 b$ & $0.0353 b$ & $0.0360 \mathrm{~b}$ & $0.0377 \mathrm{ab}$ & $0.0412 \mathrm{a}$ & 0.0051 & 0.13 \\
\hline Protein & $0.0353 \mathrm{a}$ & $0.0338 \mathrm{a}$ & $0.0339 a$ & $0.0334 \mathrm{a}$ & $0.0343 \mathrm{a}$ & 0.0970 & 0.05 \\
\hline Lactose & $0.0436 \mathrm{a}$ & $0.0438 \mathrm{a}$ & $0.0437 \mathrm{a}$ & $0.0436 \mathrm{a}$ & $0.0429 \mathrm{~b}$ & 0.0063 & 0.03 \\
\hline Acidity $\left({ }^{\circ} \mathrm{D}\right)$ & $14 \mathrm{a}$ & $14 \mathrm{a}$ & $14 \mathrm{a}$ & $14 \mathrm{a}$ & $14 \mathrm{a}$ & 0.7761 & 0.004 \\
\hline
\end{tabular}

Means followed by different letters in the row differ by Tukey's test $(\mathrm{P}<0.05)$.

TSCMY - milk yield corrected for total solids; FE - feed efficiency.

${ }^{1}$ FCMY 0.04 - milk yield corrected for 0.04 percentage of the fat.

cases, there is reduction or increases, and in others cases, no interference (Fernandes et al., 2002; Queiroga et al., 2009).

Silva et al. (2010) studied whole cottonseed as a source of lipid supplementation and found no difference in milk production when compared with the control diet (soybean meal), but when supplemented with faveleira cake, there was a decrease in milk production, and the values of 1.098 and $1.095 \mathrm{~kg} /$ day of milk for whole cottonseed and faveleira cake, respectively, shown by these authors are below those found in this study. It is noteworthy that the animals used in the experiment of these authors had average milk production of $1.20 \mathrm{~kg} /$ day, i.e., well below the $2.00 \mathrm{~kg} /$ day of animals used in this study, which leads us to infer that diets with $\mathrm{CC}+\mathrm{U}$ and $\mathrm{WC}+\mathrm{U}$ can be alternatives to animals with lower milk production.

The physicochemical composition of milk differed $(\mathrm{P}<0.05)$ for total solids $(\mathrm{TS})$, moisture, fat and lactose, which were higher in the milk of animals receiving diets with $\mathrm{WC}+\mathrm{U}$, except for lactose, not differing only from goats fed the diet $\mathrm{CC}+\mathrm{U}$ for fat percentage $(\mathrm{P}>0.05)$.

The fat percentage in the milk of goats fed diets containing $\mathrm{WC}+\mathrm{U}$ and $\mathrm{CC}+\mathrm{U}$, of 0.0412 and 0.0377 , respectively, were the highest, and these results corroborate those reported by Silva et al. (2010), who found that there is an increase in the TS and fat percentage in the milk of goats fed faveleira cake and whole cottonseed as lipid supplement in the diet with soybean meal. Smith et al. (1981) and Lubis et al. (1990) reported that diets with whole cottonseed decrease the synthesis of short-chain fatty acids in the mammary gland, but there is a transfer of long-chain fatty acids of whole cottonseed to the milk, which results in a net increase in the percentage and production of milk fat. Higher levels of fat and total solids in milk are desirable characteristics in the dairy industry, because they promote an increase in product yield (Santos et al., 2011).

The percentage of protein in milk did not differ among diets, with average percentage of 0.0341 , above the 0.0299 found by Macedo et al. (2003), but similar to the 0.0369 observed by Araújo et al. (2010). It was expected that the different sources of protein would promote changes in the protein content, which was not observed in this study, since soybean meal, which is a food rich in rumen-degradable protein (RDP), was replaced by three sources of protein (cottonseed meal, cottonseed cake and whole cottonseed), with higher levels of rumen-undegradable protein (RUP). The quality of RUP from these sources compared with soybean meal may have contributed to these results (Goetsch et al., 2011). Laudadio \& Tufarelli (2010) found higher values for protein percentage in the milk of goats fed diets containing high RUP levels, and according to these authors, this may occur as a result of better utilization of nutrients. However, Huston \& Hart (2002) reported that the response of lactating goats to RUP supplementation is lower when compared with cows; moreover, the response to RUP supplementation is more evident in high-yielding animals (Chalupa \& Sniffen, 1991). In extreme cases, the protein percentage in milk is around 0.004 , while the fat percentage can vary from 0.02 to 0.03 (Carvalho, 2000). 
Between protein and fat, fat is more strongly influenced by nutrition (Pulina et al., 2008).

The average percentage value of 0.0435 for lactose in the milk of animals in the present study is similar to 0.043 , recommended by current Brazilian legislation for goat milk (Brasil, 2000) and equal to 0.0435 found by Macedo et al. (2003), who found no difference in lactose and protein levels when substituting up to 0.5 soybean meal by corn gluten in the diet of lactating goats, unlike animals fed a diet containing $\mathrm{WC}+\mathrm{U}$, which showed the percentage of 0.0429 for lactose in milk lower than the other treatments $(\mathrm{P}<0.05)$; the lower NFC consumption by these animals may have contributed to reduced production of propionate and consequently its availability in the mammary gland for use in the synthesis of lactose (Goestich et al., 2001). Like protein, the lactose content of milk can hardly be changed (Carvalho, 2000).

The titratable acidity value of $14^{\circ} \mathrm{D}$, average for all treatments, is within the limits for goat milk, which ranges from 13 to $18{ }^{\circ} \mathrm{D}$ (Brasil, 2000), demonstrating the milk quality regarding its collection and manipulation.

Nitrogen intake (g/day) showed the same behavior as protein intake (Table 3), in which animals fed the diet containing SBM had higher nitrogen intake when compared with animals fed the diet containing $\mathrm{CC}+\mathrm{U}$ and $\mathrm{WC}+\mathrm{U}$ $(\mathrm{P}<0.05)$ (Table 5). The excretion of nitrogen in milk (g/day) was higher in animals that received the diet containing SBM than for those fed the diet containing $\mathrm{CM}+\mathrm{U}, \mathrm{CC}+\mathrm{U}$ and $\mathrm{WC}+\mathrm{U}(\mathrm{P}<0.05)$ as a result of the difference in milk production among animals (Table 4). Among the diets, with the use of cotton-derived products associated with urea as sources of nitrogen, animals receiving $\mathrm{CM}+\mathrm{U}$ had higher fecal nitrogen excretion ( $\mathrm{g} /$ day) $(\mathrm{P}<0.05)$, not differing from the diets containing $\mathrm{SBM}$ and $\mathrm{SBM}+\mathrm{U}(\mathrm{P}>0.05)$. There was no difference in nitrogen excretion in urine and nitrogen balance (NB) in $\mathrm{g}$ /day between sources of nitrogen studied $(\mathrm{P}>0.05)$, and NB was negative regardless of the source of nitrogen used in the diet. Difference was detected $(\mathrm{P}<0.05)$ for nitrogen use efficiency (NE).

The higher nitrogen intake (g/day) and nitrogen excretion in milk ( $\mathrm{g} /$ day) of animals fed diets containing SBM when compared with those fed $\mathrm{CC}+\mathrm{U}$ and $\mathrm{WC}+\mathrm{U}$ $(\mathrm{P}<0.05)$ was due to the difference between DM intake and milk yield; these variables were higher in animals fed diets containing SBM compared with animals fed diets containing $\mathrm{CC}+\mathrm{U}$ and $\mathrm{WC}+\mathrm{U}$. Animals that received diet with $\mathrm{CM}+\mathrm{U}$ had lower $\mathrm{CP}$ digestibility, which increases fecal nitrogen excretion (Van Soest, 1994) and explains the higher fecal nitrogen excretion ( $\mathrm{g} /$ day), not differing from diets containing $\mathrm{SBM}$ and $\mathrm{SBM}+\mathrm{U}(\mathrm{P}>0.05)$.

As previously mentioned, $\mathrm{CP}$ intake by goats fed diets containing SBM, SBM+U and $\mathrm{CM}+\mathrm{U}$ was close to values recommended by the NRC (2007), and all animals, regardless of the treatment, showed negative nitrogen balance; however, the presence of significance for NE shows that animals fed $\mathrm{CC}+\mathrm{U}$ and $\mathrm{WC}+\mathrm{U}$ were less efficient in the use of nitrogen for the synthesis of milk. The values observed in this study were lower than those reported by Jonker et al. (1998), who found an average coefficient of $0.283 \pm 0.037$ $(\mathrm{n}=70)$ for nitrogen use efficiency by analyzing data from 40 cows and 10 diets in the development of a model for predicting nitrogen use efficiency.

For Cordeiro et al. (2007), lower nitrogen use efficiency may be associated with the amino acid profile required for lactating animals, because from the moment they do not meet the requirements for milk production, amino acids supplied by diet and/or by rumen microorganisms are used in other metabolic pathways.

The use efficiency of nitrogen derived from rumen degradable protein depends on the level of energy intake from carbohydrates of high degradation rate (NFC) and animals fed diets containing $\mathrm{CC}+\mathrm{U}$ and $\mathrm{WC}+\mathrm{U}$ had the lowest NFC intake when compared with the control diet (Table 3). Chase (2003), cited by Pina et al. (2006), in

Table 5 - Nitrogen balance and use efficiency by lactating goats receiving different sources of nitrogen in the diet

\begin{tabular}{|c|c|c|c|c|c|c|c|}
\hline \multirow[b]{2}{*}{ Item } & \multicolumn{7}{|c|}{ Treatments } \\
\hline & Soybean meal & $\begin{array}{l}\text { Soybean meal } \\
+ \text { urea }\end{array}$ & $\begin{array}{l}\text { Cottonseed meal } \\
+ \text { urea }\end{array}$ & $\begin{array}{l}\text { Cottonseed cake } \\
+ \text { urea }\end{array}$ & $\begin{array}{l}\text { Whole cottonseed } \\
+ \text { urea }\end{array}$ & P-value & $\begin{array}{c}\text { Standard error of } \\
\text { the mean }\end{array}$ \\
\hline $\mathrm{N}$ intake (g/day) & $49.6 \mathrm{a}$ & $47.6 \mathrm{a}$ & $45.5 \mathrm{ab}$ & $42.3 b c$ & $37.1 \mathrm{c}$ & 0.0001 & 0.001 \\
\hline $\mathrm{N}$ milk (g/day) & $11.3 \mathrm{a}$ & $10.0 \mathrm{ab}$ & $9.2 \mathrm{bc}$ & $7.7 \mathrm{~cd}$ & $6.6 \mathrm{~d}$ & 0.0001 & 0.000 \\
\hline $\mathrm{N}$ feces (g/day) & $13.0 \mathrm{ab}$ & $12.9 \mathrm{ab}$ & $15.3 \mathrm{a}$ & $12.7 \mathrm{bc}$ & $10.2 \mathrm{c}$ & 0.0001 & 0.000 \\
\hline \multicolumn{8}{|l|}{ Efficiency } \\
\hline $\mathrm{NE}-\mathrm{N}$ milk/N intake $(\mathrm{g} / \mathrm{g})$ & $0.22 \mathrm{a}$ & $0.20 \mathrm{ab}$ & $0.19 \mathrm{ab}$ & $0.17 \mathrm{~b}$ & $0.17 \mathrm{~b}$ & 0.0012 & 0.008 \\
\hline
\end{tabular}

Means followed by different letters in the row differ by Tukey's test $(\mathrm{P}<0.05)$.

$\mathrm{NE}$ - nitrogen use efficiency. 
an attempt to identify the various factors that affect the nitrogen use efficiency, reported among other factors, the quantity and quality of dietary protein, as well as the source of carbohydrates.

\section{Conclusions}

The use of soybean meal and cottonseed meal associated with urea as main source of nitrogen in the diet for lactating goats does not compromise the milk performance and characteristics. This study recommends the use of cottonseed cake and whole cottonseed associated with urea when feeding animals in the period of low milk production.

\section{References}

ALLEN, M.S. Effects of diet on short-term regulation of feed intake by lactating dairy cattle. Journal of Dairy Science, v.83, n.7, p.1598-1624, 2000.

ANKOM, 2003. Method for determining neutral detergent fiber (aNDF) and in vitro true digestibility using the DAISYII incubator. ANKOM Technology, Macedon, NY. Available at: $<$ http://www.ankom.com/09 procedures/> Accessed on: Jan. 11, 2010.

ARAÚJO, M.J.; MEDEIROS, A.N.; SILVA, D.S. et al. Produção e composição do leite de cabras Moxotó submetidas a dietas com feno de maniçoba (Manihot glaziovii Muell Arg.). Revista Brasileira de Saúde e Produção Animal, v.10, n.4, p.860-873, 2010.

ASSOCIATION OF OFFICIAL ANALYTICAL CHEMISTS AOAC. Official methods of analysis. 14.ed. Washington, D.C., 1990. p.129-130.

ASSOCIATION OF OFFICIAL ANALYTICAL CHEMISTS AOAC. Official methods of analysis. 16.ed. Washington, D.C., 1998. 4 rev., $2 \mathrm{v}$.

BERAN, F.H.B.; SILVA, L.D.F.; RIBEIRO, E.L.A. et al. Degradabilidade ruminal "in situ" da matéria seca, matéria orgânica e proteína bruta de alguns suplementos concentrados usados na alimentação de bovinos. Semina: Ciências Agrárias, v.26, n.3, p.405-418, 2005.

BOMFIM, M.A.D.; SILVA, M.M.C.; SANTOS, S.F. Potencialidades da utilização de subprodutos da indústria de biodiesel na alimentação de caprinos e ovinos. Tecnologia \& Ciência Agropecuária, v.3, n.4, p.15-26, 2009.

BRASIL. Ministério da Agricultura e do Abastecimento. Secretaria Nacional de Defesa Agropecuária. Instrução Normativa $n^{\circ} 37$. Regulamento técnico de produção, identidade e qualidade do leite de cabra. Diário Oficial da União, Brasília, 8 nov. 2000. Seção 1, p.23-25.

BROWN-CROWDER, I.E.; HART, S.P.; CAMERORN, M. et al. Effects of dietary tallow level on performance of Alpine does in early lactation. Small Ruminant Research, v.39, n.3, p.233-241, 2001.

CANNAS, A.; TEDESCHI, L.O.; FOX, D.G. Prediction of metabolizable energy intake and energy balance of goats with the Small Ruminant Nutrition System. In: INTERNATIONAL SYMPOSIUM ON ENERGY AND PROTEIN METABOLISM AND NUTRITION, 2., 2007, Vichy, France. Proceedings... Vichy, France, 2007b. 569-570p.

CARVALHO, M.P. Manipulação da composição do leite por meio de balanceamento de dietas de vacas leiteiras. In: FONSECA, L.F.L.; SANTOS, M.V. (Eds.) Qualidade do leite e controle de mastite. São Paulo: Lemos, 2000. p.163-169.
CASALI, A.O. Procedimentos metodológicos in situ na avaliação do teor de compostos indigestíveis em alimentos e fezes de bovinos. 2006. 47f. Dissertação (Mestrado em Zootecnia) Universidade Federal de Viçosa, Viçosa, MG.

CHALUPA, W.; SNIFFEN, C. Protein and amino acid nutrition of lactating dairy cattle. Veterinary Clinics of North America: Food Animal Practice, v.7, n.2, p.353-372, 1991.

CLARK, J.H.; KLUSMEYER. T.H.; CAMERON, M.A. Microbial protein sinthesys and flows of nitrogen fractions to the duodenum of dairy cows. Journal of Dairy Science, v.75, n.8, p.2304-2323, 1992.

CORDEIRO, C.F.A.; PEREIRA, M.L.A.; MENDONÇA, S.S. et al. Consumo e digestibilidade total dos nutrientes e produção e composição do leite de vacas alimentadas com teores crescentes de proteína bruta na dieta contendo cana-de-açúcar e concentrados. Revista Brasileira de Zootecnia, v.36, n.6, p.2118-2126, 2007.

FERNANDES, J.J.R.; PIRES, A.V.; SANTOS, F.A.P. et al. Teores de caroço de algodão em dietas contendo silagem de milho para vacas em lactação. Acta Scientiarum, v.24, n.4, p.1071-1077, 2002.

FONSECA, C.E.M.; VALADARES, R.F.D.; VALADARES FILHO, S.C. et al. Estimativa da produção microbiana em cabras lactantes alimentadas com diferentes teores de proteína na dieta. Revista Brasileira de Zootecnia, v.35, n.3, p.1169-1177, 2006 (supl.).

GOETSCH, A.L.; DETWEILER, G.; SALHU, T. et al. Dairy goat performance with different dietary concentrate levels in late lactation. Small Ruminant Research, v.41, n.2, p.117-125, 2001.

GOETSCH, A.L.; ZENG, S.S.; T.A. GIPSON. Factors affecting goat milk production and quality. Small Ruminant Research, v.101, n.1, p.55-63, 2011.

HALL, M.B. Calculation of non-structural carbohydrate content of feeds that contain non-protein nitrogen. Gainesville: University of Florida, 2000. p.A-25. (Bulletin 339).

HARMEYER, J.; MARTENS, H. Aspects of urea metabolism with reference to the goat. Journal of Dairy Science, v.63, n.10, p.1707-1728, 1980.

HUSSAIN, Q.; HAVREVOLL, Ø.; EIK, L.O. Effect of type of roughage on feed intake, milk yield and body condition of pregnant goats. Small Ruminant Research, v.22, n.2, p.131-139, 1996.

HUSTON, J.E.; HART, S.P. Goat husbandry: Feeding management. In: ROGINSKI, J.W.; FUQUAY, J.W.; FOX, P.F. (Eds.) Encyclopedia of Dairy Sciences. v.2. Maryland Heights, MO: Academic Press, 2002. p.1235-1243.

INSTITUTO ADOLFO LUTZ - IAL. Normas analíticas do Instituto Adolfo Lutz. São Paulo: Instituto Adolfo Lutz, 2005. 1018p.

JENKINS, T.C. Lipid metabolism in the rumen. Journal of Dairy Science, v.76, n.12, p.3851-3863, 1993

JONKER, J.S.; KOHN, R.A.; ERDMAN, R.A. Using milk urea nitrogen to predict nitrogen excretion and utilization efficiency in lactating dairy cows. Journal of Dairy Science, v.81, n.10, p.2681-2691, 1998.

LAUDADIO, V.; TUFARELLI, V. Effects of pelleted total mixed rations with different rumen degradable protein on milk yield and composition of Jonica dairy goat. Small Ruminant Research, v.90, n. 1, p.47-52, 2010.

LICITRA, G.; HERNANDEZ, T.M.; VAN SOEST, P.J. Standardization of procedures for nitrogen fractionation of ruminant feeds. Animal Feed Science and Technology, v.57, n.4, p.347-358, 1996.

LUBIS, D.; VAN HORN, H.H.; HARRIS, B. et al. Responses of lactating dairy cows to protected fats or whole cottonseed in low or high forage diets. Journal of Dairy Science, v.73, n.12, p.3512-3525, 1990.

LUO, J.; GOETSCH, A.L.; NSAHLAI, I.V. et al. Maintenance energy requirements of goats: predictions based on observations of heat and recovered energy. Small Ruminant Research, v.53, n.3, p.221-230, 2004.

MACEDO, L.G.P.; DAMASCENO, J.C.; MARTINS, E.N. et al. Substituição do farelo de soja pela farinha de glúten de milho na alimentação de cabras leiteiras. Revista Brasileira de Zootecnia, v.32, n.4, p.992-1001, 2003. 
MERTENS, D.R. Análise da fibra e sua utilização na avaliação e formulação de rações. In: SIMPÓSIO INTERNACIONAL DE RUMINANTES, REUNIÃO ANUAL DA SOCIEDADE BRASILEIRA DE ZOOTECNIA, 29., 1992, Lavras. Anais... Lavras: Sociedade Brasileira de Zootecnia, 1992. p.188-219.

MERTENS, D.R. Regulation of forage intake evaluation and utilization. Nebraska: American Soil Science of America, 1994. 988p.

MERTENS, D.R. Gravimetric determination of amylase-treated neutral detergent fiber in feeds with refluxing in beakers or crucibles: collaborative study. Journal of AOAC International, v.85, n.6, p.1217-1240, 2002.

MOE, P.W.; FLATT, W.P.; TYRREL, H.F. Net energy value of feeds for lactation. Journal of Dairy Science, v.55, n.7, p.945, 1972.

NATIONAL RESEARCH COUNCIL - NRC. Nutrient requirements of dairy cattle. 7.ed.rev. Washington: National Academy of Science, 2001. 381p.

NATIONAL RESEARCH COUNCIL - NRC. Nutrient requirement of small ruminants. 1.ed. Washington: NAP, 2007. 362p.

PALMQUIST, D.L. Influence of source and amount of dietary fat on digestibility in lactating cows. Journal of Dairy Science, v.74, n.4, p.1354-1360, 1991

PINA, D.S.; VALADARES FILHO, S.C.; VALADARES, R.F.D. et al. Consumo e digestibilidade aparente total dos nutrientes, produção e composição do leite de vacas alimentadas com dietas contendo diferentes fontes de proteína. Revista Brasileira de Zootecnia, v.35, n.4, p.1543-1551, 2006.

PULINA, G.; NUDDA, A.; BATTACONE, G. Nutrition and quality of goat's milk. In: PULINA, G.; CANNAS, A. (Eds.) Dairy goats feeding and nutrition. 2.ed. Bologna: CAB International, 2008. p.1-30.

QUEIROGA, R.C.R.E.; FERNANDES, M.F.; MEDEIROS, A.N. et al. Physicochemical and sensory effects of cotton seed and sunflower oil supplementation on Moxotó goat milk. Small Ruminant Research, v.82, n.1, p.58-61, 2009.
RUSSEL, J.B.; O'CONNOR, J.D.; FOX, D.G. et al. A Net Carbohydrate and Protein System for evaluating cattle diets. I. Ruminal fermentation. Journal of Animal Science, v.70, n.11, p.3551-3561, 1992.

SANTOS, N.A.F.; LACERDA, L.M.; RIBEIRO, A.C. et al. Avaliação da composição e qualidade físico-química do leite pasteurizado pradonizado comercializado na cidade de São Luís, MA. Arquivos do Instituto Biológico, v.78, n.1, p.109-113, 2011.

SHORT, R.E.; ADAMS, D.C. Nutritional and hormonal interrelationships in beef cattle reproduction. Canadian Journal of Animal Science, v.68, n.1, p.29-39, 1988.

SILVA, D.J.; QUEIROZ, A.C. Análise de alimentos: métodos químicos e biológicos. Viçosa, MG: UFV, 2002. 235p.

SILVA, G.L.S.; SILVA, A.M.A.; NÓBREGA, G.H. et al. Consumo, digestibilidade e produção de cabras leiteiras alimentadas com dietas contendo diferentes fontes de lipídios. Acta Scientiarum Animal Sciences, v.32, n.1, p.47-53, 2010.

SILVA, M.M.C.; RODRIGUES, M.T.; BRANCO, R.H. et al. Suplementação de lipídios em dietas para cabras em lactação: consumo e eficiência de utilização de nutrientes. Revista Brasileira de Zootecnia, v.36, n.1, p.257-267, 2007.

SMITH, N.E.; COLLAR, L.S.; BATH, D.L. et al. Digestibility and effects of whole cottonseed fed to lactating cows. Journal of Dairy Science, v.64, n.11, p.2209-2215, 1981.

TILLEY, J.M.A.; TERRY, R.A. A two stage technique for the in vitro digestion of forage crops. Journal of the British Grassland Society, v.18, n.2, p.104-111, 1963.

TYRREL, H.F.; REID, J.T. Prediction of energy value of cow's milk. Journal of Dairy Science, v.48, n.9, p.1215-1223, 1965.

VAN SOEST, P.J. Nutritional ecology of the ruminant. 2.ed. Ithaca: Cornell University Press, 1994. 476p.

WU, Z.; SATTER, L.D. Milk production during the complete lactation of dairy cows fed diets containing different amounts of protein. Journal of Dairy Science, v.83, n.5, p.1042-1051, 2000. 